\title{
SOIL MICROBIAL BIOMASS UNDER DIFFERENT MANAGEMENT AND TILLAGE SYSTEMS OF PERMANENT INTERCROPPED COVER SPECIES IN AN ORANGE ORCHARD ${ }^{(1)}$
}

\author{
Elcio Liborio Balota ${ }^{(2)}$ \& Pedro Antonio Martins Auler ${ }^{(3)}$
}

\begin{abstract}
SUMMARY
To mitigate soil erosion and enhance soil fertility in orange plantations, the permanent protection of the inter-rows by cover species has been suggested. The objective of this study was to evaluate alterations in the microbial biomass, due to different soil tillage systems and intercropped cover species between rows of orange trees. The soil of the experimental area previously used as pasture (Brachiaria humidicola) was an Ultisol (Typic Paleudult) originating from Caiuá sandstone in the northwestern part of the State of Paraná, Brazil. Two soil tillage systems were evaluated: conventional tillage (CT) in the entire area and strip tillage (ST) (strip width $2 \mathrm{~m}$ ), in combination with different ground cover management systems. The citrus cultivar 'Pera' orange (Citrus sinensis) grafted onto 'Rangpur' lime rootstock was used. Soil samples were collected after five years of treatment from a depth of 0-15 cm, under the tree canopy and in the inter-row, in the following treatments: (1) CT and an annual cover crop with the leguminous species Calopogonium mucunoides; (2) CT and a perennial cover crop with the leguminous peanut Arachis pintoi; (3) CT and an evergreen cover crop with Bahiagrass Paspalum notatum; (4) CT and a cover crop with spontaneous Brachiaria humidicola grass vegetation; and (5) ST and maintenance of the remaining grass (pasture) of Brachiaria humidicola. Soil tillage and the different cover species influenced the microbial biomass, both under the tree canopy and in the interrow. The cultivation of brachiaria increased $\mathrm{C}$ and $\mathrm{N}$ in the microbial biomass, while bahiagrass increased $P$ in the microbial biomass. The soil microbial biomass was enriched in $\mathrm{N}$ and $\mathrm{P}$ by the presence of ground cover species and according to the soil $\mathrm{P}$ content. The grass species increased $\mathrm{C}, \mathrm{N}$ and $\mathrm{P}$ in the soil microbial biomass from the inter-row more than leguminous species.
\end{abstract}

Index terms: microbial activity, soil tillage, nutrient cycling, citrus management.

\footnotetext{
(1) Received for publication in December 11, 2009 and approved August 26, 2011.

(2) Research Scientist at the Soil Department of Agricultural Institute of Paraná - IAPAR, Caixa Postal 481, CEP 86001-970 Londrina (PR), Brasil. E-mail: balota@iapar.br

(3) Research Scientist at the Crop Science Department of IAPAR, Caixa Postal 564, CEP 87701-970 Paranavai (PR), Brazil. Email: aulerpe@iapar.br
} 


\title{
RESUMO: BIOMASSA MICROBIANA SOB SOLO COM DIFERENTES SISTEMAS DE PREPARO E CULTIVO INTERCALAR DE COBERTURAS PERMANENTES EM POMAR DE LARANJEIRA
}

\begin{abstract}
Tem sido sugerido que a área intercalar em pomar de laranjeira deve permanecer permanentemente protegida por espécies de cobertura vegetal, objetivando diminuir a erosão do solo e aumentar a sua fertilidade. No presente trabalho foram avaliadas as alterações na atividade microbiana devido os diferentes sistemas de preparo do solo e o cultivo intercalar de coberturas permanente em pomar de laranjeira. O experimento foi conduzido no noroeste do Paraná em um Argissolo Vermelho distrófico latossólico textura arenosa / média originado do arenito Caiuá, em área previamente ocupada por pastagem (Brachiaria humidicola). Foram estudados dois sistemas de preparo do solo (preparo convencional [PC] e preparo em faixa $[P F])$ e diferentes coberturas intercalar às plantas de laranjeira. Foi utilizada a laranjeira 'Pêra' (Citrus sinensis) enxertada em limoeiro 'Cravo' (Citrus limonia). As amostras de solo foram coletadas cinco anos após a instalação do experimento na profundidade de 0-15 $\mathrm{cm}$ sob a projeção da copa e na entrelinha nos seguintes tratamentos: (1) PC e cobertura vegetal com a leguminosa anual Calopogonium mucunoides; (2) PC e cobertura vegetal com a leguminosa perene amendoim forrageiro Arachis pintoi; (3) PC e cobertura vegetal com a gramínea matogrosso ou batatais Paspalum notatum; (4) PC e cobertura com a vegetação espontânea da graminea Brachiaria humidicola; (5) ST e cobertura com a manutenção da gramínea remanescente da pastagem, Brachiaria humidicola. O preparo do solo e as diferentes coberturas vegetais influenciaram a biomassa microbiana tanto na projeção da copa como na entrelinha. $O$ cultivo de brachiaria aumentou o teor de $C$ e $N$ da biomassa microbiana, enquanto que a grama mato grosso aumentou o teor de P. A biomassa microbiana foi enriquecida com $N$ e $P$ devido às diferentes coberturas intercalares e aos teores de $P$ no solo. A diminuição do revolvimento do solo aumentou a biomassa microbiana na entrelinha. O cultivo de gramíneas aumentou os teores de $C, N$ e $P$ da biomassa microbiana na entrelinha comparada com o cultivo de leguminosas.
\end{abstract}

Termos de indexação: atividade microbiana, preparo do solo, ciclagem de nutrientes, manejo de pomar de Citros.

\section{INTRODUCTION}

Most part of the soils cultivated with citrus in the Paraná State originated from geological Caiuá sandstone that has a low clay content, low natural fertility and a high water erosion potential. Due to these Characteristics, conservation management systems have been suggested for the inter-row in orange plantations, aiming to mitigate soil erosion and enhance soil fertility by a permanent protection with groundcover species (Fidalski et al., 2007; Auler et al., 2008).

Soil conservation management systems have also been studied in orange orchards in view of the soil disturbance caused by the conventional tillage, with the removal or incorporation of plant residues into soil, favoring the occurrence of erosive processes, mainly in the early phase of orchard establishment (Politano \& Pissarra, 2005).

The use of cover species in the inter-row between perennial crops is one of the most efficient practices that can be applied separately to minimize soil erosion, for influencing the very origin of erosion. Crop residues protect the soil against the high energy of raindrops, avoiding soil particle disaggregation and allowing greater water infiltration. In addition, the cover crops improve the soil chemical, physical and biological properties (Chaves et al., 1997). Conservation tillage systems can also improve soil quality (Dick, 1992). The formation and stabilization of soil macroaggregates are important for protecting and maintaining the soil organic matter. Long-term conventional tillage results in low aggregate stability and poor physical protection of soil organic mater, which is decomposed at high rates by heterotrophic soil microorganisms (Beare et al., 1994). The changes in the structure can affect soil water, temperature, aeration, the equilibrium of reactions, and can increase soil erosion. The decrease of soil disturbance associated with cover species between the trees in perennial crop systems can change the soil habitat by affecting the nutrient status, root depth, residue amount and quality, the aggregation/microbial habitat, and can stimulate soil microbial diversity and activity (Dick, 1992; Balota et al., 2004). Soil microorganisms mediate the decomposition of soil organic matter (SOM) and nutrient mineralization. The microbial biomass is a small, but important reservoir of nutrients $(\mathrm{C}$, $\mathrm{N}, \mathrm{P}$ and S). Many transformations of these nutrients occur in the microbial biomass (Dick, 1992). Microbial biomass is therefore a fundamental component of 
nutrient cycling in agro-ecosystems. Soil disturbance can cause significant modifications in the soil habitat, affecting the microbial community.

On the other side, the effects of different ground cover species on microbial biomass and activity have received much less attention. There are indications that a great part of the benefits of cover species come from the improvement of microbial diversity (Dick, 1992; Kaschuk et al., 2010), which plays a fundamental role in the nutrient cycle and, consequently, in plant nutrition (Smith \& Paul, 1990; Sparling, 1997).

The objective of this study was to evaluate the effect of tillage systems and groundcover species on soil microbial biomass in an orange orchard.

\section{MATERIALS AND METHODS}

\section{Experimental conditions}

The experiment was established in 1993 in Alto Paraná, in the northwestern part of the State of Paraná $\left(23^{\circ} 05^{\prime} \mathrm{S}, 52^{\circ} 26^{\prime} \mathrm{W}\right)$. The sandy Ultisol soil was classified as Typic Paleudult (American Soil Taxonomy; Soil Survey Staff, 1999) and Argissolo Vermelho distrófico latossólico (Brazilian Classification System; Bhering \& Santos, 2008) that originated from Caiuá sandstone. This soil consisted of $90 \%$ sand; $2 \%$ silt; $8 \%$ clay; with $\mathrm{pH}=3.9\left(\mathrm{CaCl}_{2}\right) ; 1.9 \mathrm{mg} \mathrm{kg}^{-1}$ $\mathrm{P}$ (Mehlich-1); and $3.7 \mathrm{~g} \mathrm{~kg}^{-1}$ organic $\mathrm{C}$ (Walkley \& Black) that occur in the surface layer $(0-15 \mathrm{~cm})$. The experiment was conducted in an area used previously as pasture (Brachiaria humidicola), in a randomized block design, with three field replications. Each plot consisted of 15 orange trees in three plant rows containing five trees each. The trees evaluated in this study were the central three growing in the center of each plot.

Two soil tillage systems were evaluated: conventional tillage (CT) in the whole area and strip tillage (ST) with $2 \mathrm{~m}$ wide strips. Different managements of ground cover species in each tillage system were also investigated. The citrus cultivar studied was 'Pera' orange (Citrus sinensis), grafted onto 'Rangpur' lime rootstock. The conventional soil tillage (CT) system consisted in one disk plowing and two disking harrowing prior to orchard implantation. The strip tillage (ST) system consisted of soil preparation only in the $2 \mathrm{~m}$ strip, while the remaining area $(5 \mathrm{~m})$ was not tilled. The orange tree row was allocated in the center of the strip. In the ST system, only $30 \%$ of the area was tilled, leaving $70 \%$ of the area without disturbance under natural vegetation cover. Before soil tilling, $2 \mathrm{t} \mathrm{ha}^{-1}$ of dolomitic limestone was applied over the whole area. From 1996 to 1998, liming consisted in the application of annual rates of $3 \mathrm{t} \mathrm{ha}^{-1}$ under the tree canopy and $1.5 \mathrm{t} \mathrm{ha}^{-1}$ in the inter-row without soil incorporation. In both areas, a mixture of dolomitic and calcitic (1:1) limestone was applied.
The following treatments were studied: (1) CT and annual cover crop with the leguminous species Calopogonium mucunoides; (2) CT and perennial cover crop with the leguminous peanut Arachis pintoi (Krap $\&$ W.C. Greg); (3) CT and evergreen cover crop with bahiagrass Paspalum notatum (Flügge); (4) CT and cover crop with spontaneous Brachiaria humidicola grass vegetation; and (5) ST and maintenance of the remaining pasture grass of Brachiaria humidicola. The cover vegetation was controlled using a mower whenever necessary. Additional information about the experiment can be found in Fidalski et al. (2007) and Auler et al. (2008).

Annually, from September to March, mineral fertilizers (NPK) were applied under the tree canopy of the orange trees. The fertilizer was applied at rates of $140 \mathrm{~kg} \mathrm{ha}^{-1} \mathrm{~N}, 50 \mathrm{~kg} \mathrm{ha}^{-1} \mathrm{P}_{2} \mathrm{O}_{5}$ and $110 \mathrm{~kg} \mathrm{ha}^{-1}$ $\mathrm{K}_{2} \mathrm{O}$, as ammonium sulfate, simple superphosphate and potassium chloride, respectively. The $\mathrm{N}$ was split in four, $\mathrm{K}$ in two and $\mathrm{P}$ in one application.

\section{Soil sampling}

Five soil sub-samples were collected from the layer $0-15 \mathrm{~cm}$ in each replication under the tree canopy and in the middle of the inter-rows in two seasons: at the end of the summer (March) and in spring (October), from 1997 to 1998, beginning about five years after the experiment started. The fresh soil samples were sieved (4 mm), large plant material was removed, and samples were stored at $4^{\circ} \mathrm{C}$ until analysis of the microbial and chemical properties.

\section{Soil chemical and microbial analysis}

The soil chemical analyses were performed according to Pavan et al. (1992). The microbial biomass C (MBC) was determined by a fumigationextraction method according to Vance et al. (1987), using a correction factor $\left(\mathrm{k}_{c}\right)$ of 0.33 . The microbial biomass N (MBN) was determined by the method of Brookes et al. (1985), using a correction factor of 0.54. The microbial biomass $\mathrm{P}$ (MBP) was determined in a fumigation-extraction according to the method of Brookes et al. (1982), using a factor $\left(\mathrm{k}_{p}\right)$ of 0.4. All determinations were conducted in triplicate and expressed as dry weight.

\section{Nutrient stock and flux through microbial biomass}

The $\mathrm{C}$ stock, microbial biomass $\mathrm{C}, \mathrm{N}$ and $\mathrm{P}$ were calculated from the organic $\mathrm{C}$ and microbial biomass $\mathrm{C}, \mathrm{N}$ and $\mathrm{P}$ concentrations measured in each treatment, multiplied by the respective bulk density and thickness of the soil layer. The soil bulk density $\left(\mathrm{kg} \mathrm{dm}^{-3}\right)$ was 1.64 for C. mucunoides and A. pintoi, 1.63 for Bahiagrass and 1.67 for B. humidicola (Fidaslki et al., 2007). The annual flux of $\mathrm{C}, \mathrm{N}$ and $\mathrm{P}$ through the microbial biomass was estimated by considering a 1.25 turnover time for the nutrient stocked in 
microbial biomass as proposed by Jenkinson \& Ladd (1981) for tropical and subtropical environments.

\section{Statistical analysis}

Of each treatment, data were averaged over the four seasons for statistical analysis (ANOVA) to determine the effects of cover species and sampling position on soil properties. Treatment effects were statistically evaluated by analysis of variance using Tukey's test to compare means at $p \leq 0.05$. The relationships between soil microbial biomass and chemical properties were analyzed by the Pearson correlation coefficient (r). All statistical analyses were performed using the statistical package SAS version 9 (SAS, 2002).

\section{RESULTS AND DISCUSSION}

\section{Chemical properties}

The chemical properties of the soils were analyzed after five years of treatment with different groundcover and soil tillage systems (Table 1). The $\mathrm{pH}$ under the tree canopy was lower (from 3.8 to 4.0 ) than in the inter-row (from 4.6 to 5.1). The acidification under the orange tree canopy was caused by various factors, including the high quantity of fertilizer applied, nutrient leaching, and the orange tree physiology (the trees absorbed high quantities of nutrients). The soil was sampled near the edge of the tree canopy, at the site of fertilizer application, where acidification processes are more intense. After five years, the degree of soil acidification under the different cover species differed, as observed elsewhere for other cover crops
(Miyazawa et al., 1992; Meda et al., 2001). The addition of organic matter to the soil contributes to the reduction of organic anion losses in the system and to an increase in $\mathrm{H}^{+}$consumption. The effects of the groundcover species on $\mathrm{Al}$ under the tree canopy differed. The increase in $\mathrm{Al}$ saturation under the tree canopy in the CT-Arachis treatment may be due to the higher capacity of leguminous species to absorb basic cations and release $\mathrm{H}^{+}$to soil solution, increasing exchangeable $\mathrm{Al}$. The low $\mathrm{Al}$ saturation in the interrow can be attributed to the $\mathrm{pH}$ increase, which reduces $\mathrm{Al}$ solubility through $\mathrm{Al}$ complexation with organic compounds (Miyazawa et al., 1992; Meda et al., 2001). Several plants have the capacity to alleviate Al toxicity through water-soluble plant organic compounds (Meda et al., 2001). This chemical change is associated with the concentrations of basic cations in the plant extract: the higher the concentration, the greater the effects of minimizing soil acidity.

The soil $\mathrm{P}$ concentration was higher under the tree canopy than in the inter-row where $\mathrm{P}$ fertilizer is applied onto the soil surface without mechanical incorporation. For this reason, the $\mathrm{P}$ content was accumulated over time. However, in the middle of the inter-row there was also an increase in the available $\mathrm{P}$ content. Available P under CT-bahiagrass increased about $142 \%$, compared to the initial content $\left(1.9 \mathrm{mg} \mathrm{kg}^{-1}\right)$. The increase of the $\mathrm{P}$ value over time in the inter-row may be explained by the $\mathrm{P}$ cycle through $\mathrm{P}$ redistribution into the undisturbed soil by different permanent groundcovers, as observed by Franchini et al. (2004) using green manure.

In all treatments, the organic $\mathrm{C}$ content was higher than observed at the beginning of experiment. The increases, on average, were around $32 \%$ under the

Table 1. Soil chemical properties (0-15 cm depth) after a 6 years of permanent cover species between the orange trees. Average of 12 replications ${ }^{(1)}$

\begin{tabular}{|c|c|c|c|c|c|c|}
\hline Treatment & $\mathrm{pH} \mathrm{CaCl}_{2}$ & Al saturation & CEC & Base saturation & $\mathbf{P}$ & $\mathbf{C}$ \\
\hline & & $\%$ & $\mathrm{cmol} \mathrm{kg}^{-1}$ & $\%$ & $\mathrm{mg} \mathrm{kg}^{-1}$ & $\mathrm{~g} \mathrm{~kg}^{-1}$ \\
\hline & \multicolumn{6}{|c|}{ Tree canopy } \\
\hline CT-Calopogonium & $3.9 \mathrm{a}$ & $36.5 \mathrm{bc}$ & 4.52 & 18.1 & $28.6 \mathrm{~b}$ & 5.4 \\
\hline CT - Arachis pintoi & $3,9 \mathrm{a}$ & $46.0 \mathrm{a}$ & 4.41 & 13.2 & $35.2 \mathrm{~b}$ & 4.5 \\
\hline CT - Bahiagrass & $3.8 \mathrm{a}$ & $39.2 \mathrm{~b}$ & 4.54 & 18.1 & $68.7 \mathrm{a}$ & 4.7 \\
\hline CT - Brachiaria & $3.8 \mathrm{a}$ & $40.8 \mathrm{~b}$ & 4.46 & 13.8 & $69.6 \mathrm{a}$ & 4.7 \\
\hline ST-Brachiaria & $4.0 \mathrm{a}$ & $34.0 \mathrm{c}$ & 4.63 & 19.3 & $66.9 \mathrm{a}$ & 5.3 \\
\hline \multirow[t]{2}{*}{ Average } & $3.8 \mathrm{~B}$ & $39.3 \mathrm{~A}$ & $4.51 \mathrm{~A}$ & $16.5 \mathrm{~B}$ & $53.8 \mathrm{~A}$ & $4.9 \mathrm{~A}$ \\
\hline & \multicolumn{6}{|c|}{ Inter-row } \\
\hline CT - Calopogonium & $4.7 \mathrm{ab}$ & 2.7 & 4.30 & 33.7 & $3.1 \mathrm{a}$ & 4.8 \\
\hline CT - Arachis pintoi & $4.6 \mathrm{~b}$ & 3.6 & 3.88 & 31.9 & $3.1 \mathrm{a}$ & 5.1 \\
\hline CT - Bahiagrass & $4.8 \mathrm{ab}$ & 1.8 & 3.86 & 34.3 & $4.6 \mathrm{a}$ & 5.6 \\
\hline CT - Brachiaria & $4.7 \mathrm{ab}$ & 3.9 & 4.12 & 32.1 & $2.6 \mathrm{a}$ & 5.3 \\
\hline ST - Brachiaria & $5.1 \mathrm{a}$ & 0.0 & 4.20 & 40.1 & $2.6 \mathrm{a}$ & 6.3 \\
\hline Average & $4.8 \mathrm{~A}$ & $2.4 \mathrm{~B}$ & $4.07 \mathrm{~A}$ & $34.4 \mathrm{~A}$ & $3.2 \mathrm{~B}$ & $5.4 \mathrm{~A}$ \\
\hline
\end{tabular}

(1) $\mathrm{pH}: \mathrm{CaCl}_{2} 0.01 \mathrm{~mol} \mathrm{~L}^{-1}$; CEC: $\mathrm{Ca}, \mathrm{Mg}, \mathrm{Al}, \mathrm{KCl} 1.0 \mathrm{~mol} \mathrm{~L}^{-1}$; P: Mehlich-1; C: Walkley-Black. CT: Conventional tillage; ST: Strip tillage. Means followed by a different lower case letter within a column of the same sampling position and upper case letter between sampling positions differ significantly by the Tukey test $(p \leq 0.05)$. 
tree canopy and $46 \%$ in the inter-row. Strip tillage (ST) with brachiaria provided an increase in organic C of up to $70 \%$ in the inter-row, compared to the initial value.

\section{Soil microbial biomass}

The average values of the microbial biomass obtained from the four samplings taken across the two years evidenced that the cultivation of different groundcover between the rows of orange trees and the soil tillage systems influenced the microbial biomass, both in the position under the tree canopy and in the inter-row.

The microbial biomass C (MBC) varied from 132 to $297 \mu \mathrm{g} \mathrm{g}^{-1}$ in the soil under tree canopy and from 279 to $481 \mu \mathrm{g} \mathrm{g}^{-1}$ in the inter-row, while the microbial biomass $\mathrm{N}(\mathrm{MBN})$ varied from 17.8 to $34.3 \mu \mathrm{g} \mathrm{g}^{-1}$, with little differences between sampling positions (Table 2). The influence of the cultivation of different cover species intercropped with the orange trees was different between the tree canopy and the inter-row. Under the tree canopy, MBC and MBN were higher under CT-calopogonium than under other groundcover species, with an increase up to 125 and $90 \%$ compared to CT-Arachis, respectively. No differences were observed in the brachiaria treatment, neither in the CT nor the ST management system. In the inter-row, the highest values of the MBC and the MBN were detected under ST-brachiaria, with 72 and $65 \%$ higher values than CT-Arachis, respectively.

Table 2. Microbial biomass $\mathrm{C}, \mathrm{N}$, and $\mathrm{P}$ under the tree canopy and in the inter-row as affected by different permanent groundcover species between the orange trees. Average of 12 replications

\begin{tabular}{llcc}
\hline \multirow{2}{*}{ Treatment $^{(1)}$} & \multicolumn{3}{c}{ Microbial Biomass } \\
\cline { 2 - 4 } & Carbon & Nitrogen & Phosphorus \\
\cline { 2 - 4 } & \multicolumn{3}{c}{ Tree canopy } \\
\cline { 2 - 4 } g $^{-1}$ soil \\
CT - Calopogonium & $297 \mathrm{a}$ & $34.3 \mathrm{a}$ & $15.7 \mathrm{~b}$ \\
CT - Arachis pintoi & $132 \mathrm{c}$ & $18.1 \mathrm{~b}$ & $10.9 \mathrm{c}$ \\
CT - Bahiagrass & $219 \mathrm{~b}$ & $21.1 \mathrm{~b}$ & $19.4 \mathrm{a}$ \\
CT - Brachiaria & $250 \mathrm{ab}$ & $34.0 \mathrm{a}$ & $13.6 \mathrm{bc}$ \\
ST - Brachiaria & $268 \mathrm{ab}$ & $29.4 \mathrm{~b}$ & $15.8 \mathrm{~b}$ \\
Average & $\mathbf{2 3 3} \mathbf{B}$ & $\mathbf{2 7 . 4} \mathbf{A}$ & $\mathbf{1 5 . 1} \mathbf{A}$ \\
& \multicolumn{3}{c}{ Inter-row } \\
CT - Calopogonium & $315 \mathrm{bc}$ & $23.7 \mathrm{~b}$ & $4.6 \mathrm{c}$ \\
CT - Arachis pintoi & $279 \mathrm{c}$ & $17.8 \mathrm{c}$ & $8.4 \mathrm{~b}$ \\
CT - Bahiagrass & $385 \mathrm{~b}$ & $21.1 \mathrm{bc}$ & $11.0 \mathrm{a}$ \\
CT - Brachiaria & $359 \mathrm{bc}$ & $26.3 \mathrm{ab}$ & $9.7 \mathrm{ab}$ \\
ST - Brachiaria & $481 \mathrm{a}$ & $29.4 \mathrm{a}$ & $10.8 \mathrm{a}$ \\
Average & $\mathbf{3 6 4} \mathbf{A}$ & $\mathbf{2 3 . 6} \mathbf{~ B}$ & $\mathbf{8 . 9} \mathbf{~ B}$ \\
\hline
\end{tabular}

(1) CT: Conventional tillage; ST: Strip tillage. Means followed by a different lower case letter within a column of the same sampling position and upper case letter between sampling positions differ significantly by the Tukey test $(p \leq 0.05)$.
The microbial biomass $\mathrm{P}$ (MBP) varied from 10.9 to $19.4 \mu \mathrm{g} \mathrm{g}^{-1}$ under the tree canopy and from 4.6 to $11.0 \mu \mathrm{g} \mathrm{g}^{-1}$ in the inter-row (Table 2). The MBP values were higher due to CT-bahiagrass, both under the tree canopy and in the inter-row. The lowest MBP values were obtained with the leguminous species Arachis pintoi under the tree canopy and Calopogonium in the inter-row. These values of microbial biomass are consistent with other studies in several Brazilian soil conditions. The values found elsewhere ranged from 84 to $1300 \mu \mathrm{g} \mathrm{g}^{-1}$ for $\mathrm{MBC}$ (Balota et al., 1998; D’Andréa et al., 2002), from 8 to $95 \mu \mathrm{g} \mathrm{g}^{-1}$ for MBN (Balota et al., 2003; Duda et al., 2003), and from 4 to 60 for MBP $\mu \mathrm{g} \mathrm{g}^{-1}$ (Rheinheimer et al., 2000) under different soil managements.

A high microbial biomass may indicate greater accumulations in the organic pool, and could represent either a sink or a source of plant-available nutrients, depending on the soil management. The higher C, N and $\mathrm{P}$ in the soil microbial biomass observed in some of the treatments may be due to a higher capacity of nutrient immobilization by the microbes from the decomposing cover species residues. The organic residues left on the soil are used as energy and nutrient source by microorganisms. In addition to the root exudates released by cover species, a large portion of the root biomass also serves as substrate for microbial growth in the soil. Different cover species contain different compounds that may affect the microbial properties in different directions and intensities.

The effects of the different cover species and tillage systems on microbial biomass were significant. In general, microbial biomass was higher under grasses. The use of grass instead of leguminous species increased the microbial biomass by about 14 and $39 \%$ for $\mathrm{C}, 8$ and $23 \%$ for $\mathrm{N}$ and 22 and $62 \%$ for $\mathrm{P}$, respectively, under the tree canopy and in the interrow. The production of total biomass residues by the different cover species was not measured in this experiment. In another experiment in the same region, total biomass residues of around $5.5 \mathrm{t} \mathrm{ha}^{-1}$ year $^{-1}$ of dry matter of Brachiaria (Beraldo et al., 2007) were produced. However, Brachiaria can produce up to $35 \mathrm{t} \mathrm{ha}^{-1}$ year $^{-1}$ of biomass dry matter (Orioli, 2008), while bahiagr.ass reaches around $7.0 \mathrm{t} \mathrm{ha}^{-1}$ year $^{-1}$ and Arachis pintoi can produce up to $30 \mathrm{t}$ of biomass dry matter ha-1 year-1 (Wendling et al., 1999). In general, the amount of the soil microbial biomass is directly related to the quantity and the quality of $\mathrm{C}$ inputs. However, other soil factors also influence the growth and activity of microorganisms.

Another fact to be considered is the large amount of roots produced and recycled annually by the cover species. Arachis pintoi can produce up to $17 \mathrm{t} \mathrm{ha}^{-1}$ of root dry matter (Valentin et al., 2001). For $B$. humidicola, a concentration of $60 \%$ of the root system was observed in the top $20 \mathrm{~cm}$, producing $2.8 \mathrm{t} \mathrm{ha}^{-1}$ and $5.4 \mathrm{t} \mathrm{ha}^{-1}$ of root dry matter, respectively, in one and seven years of cultivation (Santos et al., 2007). 
In addition to the large amount of root present in the soil, these species also release several organic compounds in the form of root exudates that have large effects on the soil microbial activity. The patterns of root exudation that vary both quantitatively and qualitatively among the plant species influence the soil microbial community and the biological processes that it regulates.

The exudates released by the roots are diverse and complex, with more than 200 carbon compounds (Kumar et al., 2006). The exudates can be released in the form of simple or complex sugar, amino acid, vitamin, organic acid, phenolic substance, enzyme, purina or nucleoside, and can occur as mucilage, cell walls, gaseous ethylene and $\mathrm{CO}_{2}$ (Whipps, 1990). Root exudates vary according to the plant species and its physiological conditions (age, nutrient status) and to the soil abiotic conditions (temperature, structure, aeration, water content). These compounds can be used immediately by microorganisms, increasing the diversity, number and activity of microorganisms in the rhizosphere. Our results suggest that different groundcover species affect the soil microbial components differently, not only due to the quantity of residues and the nutrient contents, but also due to the other organic compounds released by the shoot and root systems. It has to be pointed out that these organic compounds released by the root system are easily degradable and can be used as energy and nutrient sources for microbial growth. It is clear that root exudates are one of the largest sources of substrate for soil microbial biomass.

Microbial biomass is but a small part (5\%) of the SOM, but it is the most labile fraction, which plays an important role in nutrient cycling. The nutrients from the microbial cells are released five times faster than from decomposing soil plant cover residues (Paul \& Clark, 1996). However, the quality of the organic material that supplies energy and nutrients for the microbial biomass also influences its decomposition rate. For example, it has been observed that the MBC formed from root exudates has a rapid turnover rate, with a $50 \%$ loss in one week (Norton et al., 1990). On the other hand, about $95 \%$ of the SOM is nonliving and relatively stable, so that decades may be necessary to observe alteration (Powlson et al., 1987; Sparling, 1997). For this reason, the microbial biomass may be used as an index of soil fertility. An increase in the size of the soil microbial biomass can reflect an improvement of soil fertility (Singh et al., 2007). Due to its highly dynamic character, the microbial biomass responds more rapidly to soil fertility changes than the physical/chemical properties, which change relatively slowly (Powlson et al., 1987; Anderson \& Domsch, 1989; Sparling, 1997).

The MBC of ST-brachiaria was $34 \%$ higher and MBN and MBP approximately $12 \%$ higher than of CT-brachiaria in the inter-row, showing that a reduction in soil disturbance can improve microbial activity. Conventional tillage $(\mathrm{CT})$, where the soil is prepared by plowing and disking, reduces soil organic matter, particularly in the tropics. Soil disturbances cause an increase in organic matter oxidation and a reduction of the soil structure by degrading the soil aggregates. Macroaggregates, in particular, are susceptible to tillage degradation and are important for the protection and maintenance of soil organic matter (SOM) that can be lost under CT (Beare et al., 1994). These changes in the soil structure can affect soil water, temperature, aeration, the equilibrium of reactions, and increase soil erosion. In addition to modifications in the soil habitat due to soil disturbance, these changes can significantly deplete the microbial community (Sparling, 1997). On the other hand, the provides an increase of organic $\mathrm{C}$ source which support enhance of microbial community compared to CT. Furthermore, reduced soil disturbance favors the formation and stabilization of macroaggregates that improve and protect the habitat of microbiota (Powlson \& Jenkinson, 1981; Beare et al., 1994), improving the soil quality.

Limestone incorporation is the main reason for the use of the conventional tillage system in orchards. Fidalski \& Tormena (2005) verified the efficiency of surface liming on undisturbed soil and strip tillage. Results showed that the ST treatment, in which limestone is applied to the soil surface without incorporation, has no negative effects on the soil chemical properties $(0-40 \mathrm{~cm}$ ) or on orange yield (Auler et al., 2008). Another important piece of information resulting from this experiment reinforces the importance of cover species cultivation between orange trees. A substantial part of orange orchard soil management in Brazil consists in the maintenance of a "clean" soil surface (because the permanent intercropped vegetable cover could compete with the orange trees for soil water). However, results obtained in the same experiment show that the permanent cover crop in-between orange trees does not compete for water (Fidalski et al., 2008) nor decrease the fruit yield of the trees (Auler, 2008). These results are in agreement with the concept that a bare soil surface has negative effects, not only on the soil but also on the orange trees. Soil management systems that use vegetable cover in-between orange trees may greatly enhance orchard productivity and longevity (Neves \& Dechen, 2001).

\section{Microbial biomass ratio}

The microbial biomass $\mathrm{C} / \mathrm{N}, \mathrm{C} / \mathrm{P}$ and $\mathrm{N} / \mathrm{P}$ ratios were affected by the different cover species, soil tillage systems and sampling positions. The $\mathrm{C} / \mathrm{N}$ and $\mathrm{C} / \mathrm{P}$ microbial biomass ratios were higher in the inter-row than under the tree canopy. The $\mathrm{C} / \mathrm{N}$ microbial biomass ratio varied from 7.3 to 10.4 under the tree canopy and from 13.3 to 18.3 in the inter-row (Table 3). $\mathrm{CT}$-bahiagrass increased the $\mathrm{C} / \mathrm{N}$ microbial biomass up to $47 \%$, compared to CT-Arachis under the tree canopy, while CT-bahiagrass led to an increase of up to $38 \%$ in the inter-row, compared to CTCalopogonium. 
The microbial biomass $\mathrm{C} / \mathrm{P}$ ratio was $11.3-18.9$ under the tree canopy and $33.3-68.3$ in the inter-row (Table 3). The $\mathrm{C} / \mathrm{P}$ ratio was higher in CTCalopogonium than in the other treatments (up to $67 \%$ higher under the tree canopy and up to $105 \%$ higher in the inter-row, compared to CT-bahiagrass and CT-Arachis, respectively).

The microbial biomass N/P ratio was 1.1-2.5 under the tree canopy and 1.9-5.1 in the inter-row (Table 3). The N/P microbial biomass in the CT-brachiaria treatment was a up to $127 \%$ higher than CTbahiagrass under the tree canopy, while in the interrow the CT-Calopogonium provided an increase of up to $168 \%$ compared to CT-bahiagrass. Grass cultivation enriched $\mathrm{P}$ in the microbial biomass, decreasing the $\mathrm{C} / \mathrm{P}$ ratio by $23 \%$ and the N/P ratio under inter-row by $33 \%$.

The $\mathrm{C} / \mathrm{N}, \mathrm{C} / \mathrm{P}$ and $\mathrm{N} / \mathrm{P}$ ratios of the microbial biomass observed in this study were within the normal range mentioned in literature, with $2.2-14.1$ for $\mathrm{C} / \mathrm{N}$ (Smith \& Paul, 1990; Balota et al., 2003), 5.0 - 276 for C/P (Joergensen et al., 1995; He et al., 1997) and 1.0-4.2 for N/P (Singh \& Singh, 1993; Balota et al., 2003).

The alterations in the microbial biomass ratios observed in this study are evidence that the composition of the soil microbial community and the immobilization and mineralization rates of soil nutrients were affected according to the different cover

Table 3. The ratio of $\mathrm{C} / \mathrm{N}, \mathrm{C} / \mathrm{P}$ and $\mathrm{N} / \mathrm{P}$ microbial biomass and the $\mathrm{Cm}_{\mathrm{ic}}: \mathrm{C}_{\text {org }}$ ratio in soil under the tree canopy and the inter-row as affected by different permanent groundcover species between the orange trees. Average of 12 replications

\begin{tabular}{|c|c|c|c|c|}
\hline \multirow{2}{*}{ Treatment $^{(1)}$} & \multicolumn{4}{|c|}{ Microbial biomass ratio } \\
\hline & $\mathrm{C} / \mathrm{N}$ & $\mathrm{C} / \mathrm{P}$ & $\mathbf{N} / \mathbf{P}$ & $\mathrm{C}_{\text {mic }}: \mathrm{C}_{\text {org }}$ \\
\hline & \multicolumn{3}{|c|}{ Tree canopy } & $\%$ \\
\hline CT - Calopogonium & $8.7 \mathrm{ab}$ & $18.9 \mathrm{a}$ & $2.2 \mathrm{ab}$ & $5.5 \mathrm{a}$ \\
\hline $\mathrm{CT}$ - Arachis pintoi & $7.3 \mathrm{~b}$ & $12.1 \mathrm{~b}$ & $1.7 \mathrm{~b}$ & $2.9 \mathrm{~b}$ \\
\hline CT - Bahiagrass & $10.4 \mathrm{a}$ & $11.3 \mathrm{~b}$ & $1.1 \mathrm{c}$ & $4.7 \mathrm{ab}$ \\
\hline CT - Brachiaria & $7.4 \mathrm{~b}$ & $18.4 \mathrm{a}$ & $2.5 \mathrm{a}$ & $5.3 \mathrm{a}$ \\
\hline ST - Brachiaria & $9.2 \mathrm{ab}$ & $16.9 \mathrm{a}$ & $1.8 \mathrm{~b}$ & $5.1 \mathrm{a}$ \\
\hline \multirow[t]{2}{*}{ Average } & $8.6 \mathrm{~B}$ & $15.5 \mathrm{~B}$ & $1.8 \mathrm{~B}$ & $4.7 \mathrm{~B}$ \\
\hline & \multicolumn{4}{|c|}{ Inter-row } \\
\hline CT - Calopogonium & $13.3 \mathrm{c}$ & $68.3 \mathrm{a}$ & $5.1 \mathrm{a}$ & $6.6 \mathrm{ab}$ \\
\hline $\mathrm{CT}$ - Arachis pintoi & $15.7 \mathrm{~b}$ & $33.3 \mathrm{c}$ & $2.1 \mathrm{c}$ & $5.5 \mathrm{~b}$ \\
\hline CT - Bahiagrass & $18.3 \mathrm{a}$ & $35.0 \mathrm{c}$ & $1.9 \mathrm{c}$ & $6.9 \mathrm{ab}$ \\
\hline CT - Brachiaria & $13.7 \mathrm{c}$ & $36.9 \mathrm{c}$ & $2.7 \mathrm{~b}$ & $6.8 \mathrm{ab}$ \\
\hline ST - Brachiaria & $16.9 \mathrm{~b}$ & $45.6 \mathrm{~b}$ & $2.7 \mathrm{~b}$ & $7.8 \mathrm{a}$ \\
\hline Average & $15.6 \mathrm{~A}$ & $43.8 \mathrm{~A}$ & $2.9 \mathrm{~A}$ & $6.7 \mathrm{~A}$ \\
\hline
\end{tabular}

(1) CT: Conventional tillage; ST: Strip tillage. Means followed by a different lower case letter within a column of the same sampling position and upper case letter between sampling positions differ significantly by the Tukey test $(p \leq 0.05)$. species. The microbial biomass ratio $(\mathrm{C} / \mathrm{N}$ and $\mathrm{C} / \mathrm{P})$ can be used to indicate the likely influence of the microbial biomass on $\mathrm{N}$ and $\mathrm{P}$ availability in the soil (He et al., 1997). Low $\mathrm{C} / \mathrm{N}$ and $\mathrm{C} / \mathrm{P}$ ratios show that the biomass was enriched in $\mathrm{N}$ and $\mathrm{P}$, resulting in a high potential to release these nutrients by mineralization. On the other hand, high ratios suggest the tendency of immobilization of more available nutrients from the soil of the biomass.

The alteration of the microbial biomass $\mathrm{C} / \mathrm{N}$ ratio may be the result of changes in the microbial composition due to a change in the pattern of microbial immobilization (Smith \& Paul, 1990). Soil microbial biomass is composed of several groups of organisms. Each microbial group has a different $\mathrm{C} / \mathrm{N}$ ratio and the predominance of one group results in the prevalence of a particular ratio. The $\mathrm{C} / \mathrm{N}$ ratio of fungal hyphae is $7-12$, while that of bacteria is usually $3-6$ (Anderson \& Domsch, 1980). Plant residues left on the surface stimulate fungi population, while the incorporation of residues favors bacterial dominance (Anderson \& Domsch, 1980). The higher microbial $\mathrm{C} / \mathrm{N}$ ratio under the treatments with grasses as cover species would suggest that these sites have a greater proportion of fungi compared to bacteria than the legume treatments. That in these treatments, the proportion of fungi is greater than of bacteria.

The C/P ratio obtained in this study is within the range reported elsewhere in another region of the State of Paraná, using the same analytical methods, where the microbial biomass C/P ratio varied from 12 to 25 under an annual crop in clayey soil with high natural fertility (Balota et al., 2003), and from 26 to 106 under coffee on sandy soil with low natural fertility (Balota $\&$ Chaves, 2009). These results evidence that soil management (soil tillage or green manure cultivation) has a strong impact on the incorporation of $\mathrm{P}$ into the microbial biomass.

The higher microbial C/P ratio in the inter-row (almost three times higher) compared to the tree canopy confirms the previous observation that microbial C/P ratios depend strongly on the $\mathrm{P}$ status of the soil (Guerra et al., 1995; Conte et al., 2002). Under the tree canopy, the average of the available $\mathrm{P}$ content was almost 15 times higher than in the interrow. The higher $\mathrm{P}$ content under the tree canopy may be the reason for the lower microbial $\mathrm{C} / \mathrm{P}$ ratio, which suggests that the microbial biomass was significantly enriched with $\mathrm{P}$, with a higher potential of $\mathrm{P}$ release by mineralization.

\section{$\mathrm{C}_{\text {mic }}: \mathrm{C}_{\text {org }}$ ratio}

The ratio of the microbial biomass $\mathrm{C}$ to the organic $\mathrm{C}\left(\mathrm{C}_{\text {mic }}: \mathrm{C}_{\text {org }}\right)$ varied from 2.9 to $5.5 \%$ in the soil under the tree canopy and from 5.5 to $7.8 \%$ in the inter-row (Table 3). CT-Calopogonium led to an increase of up to $90 \%$ compared to CT-Arachis under the tree canopy, while ST-brachiaria resulted in a $42 \%$ higher $\mathrm{Cm}_{\mathrm{ic}}: \mathrm{C}_{\text {org }}$ ratio than CT-Arachis in the inter-row. 
Grass cultivation increased the $\mathrm{Cm}_{\mathrm{ic}}$ : $\mathrm{C}_{\text {org }}$ ratio by about $19 \%$ compared to legume cultivation, both under the tree canopy and in the inter-row. The results of this study were slightly higher than the range of 0.58 to 4.0 reported elsewhere under different soil and management conditions in the State of Paraná, based on the same analytical methods (Balota et al., 1998, 2004). This wide range due to the soil management suggests the high sensitivity of this ratio to express the $\mathrm{C}$ turnover pattern.

The percentage of total $\mathrm{C}$ (microbial biomass carbon-MBC) has been suggested as an indicator of whether soil organic matter is decreasing, increasing or in a steady state (Anderson \& Domsch, 1989). Changes in the $\mathrm{Cm}_{\mathrm{ic}}: \mathrm{C}_{\text {org }}$ ratio may be related to organic matter formation and the efficiency of conversion of recalcitrant $\mathrm{C}$ pools into MBC (Sparling, 1992). It has been suggested that a $\mathrm{Cm}_{\mathrm{ic}}: \mathrm{C}_{\text {org }}$ ratio of $2.2 \%$ can be expected for soil in equilibrium (Jenkinson \& Ladd, 1981). In this study, the $\mathrm{Cm}_{\mathrm{ic}}: \mathrm{C}_{\text {org }}$ ratio in all treatments was higher, which confirms the suggestions of Anderson \& Domsch (1989), because the organic C increased 22-46 \% under the tree canopy and $30-70 \%$ in the inter-row, compared to the initial content $\left(3.7 \mathrm{~g} \mathrm{~kg}^{-1}\right)$. In another study using the same soil type it was observed that in spite of a $\mathrm{C}_{\text {mic }}: \mathrm{C}_{\text {org }}$ ratio below $1.5 \%$, there was an increase of organic $\mathrm{C}$ of up to $21 \%$ compared to the initial content (Balota $\&$ Chaves, 2009). These results suggest that the $\mathrm{C}_{\text {mic }}: \mathrm{C}_{\text {org }}$ ratio under tropical/subtropical conditions compared to temperate regions may have a different threshold, as indicator of $\mathrm{C}$ accumulation. Our results show a significant enrichment of organic matter in the microbial biomass due to the Cultivation of groundcover species between the orange trees.

\section{Relationship between microbial and chemical properties}

The microbial biomass $\mathrm{C}$ and soil organic $\mathrm{C}$ were correlated, as well as these properties with $\mathrm{Cm}_{\mathrm{ic}}: \mathrm{C}_{\text {org }}$ in relation to, $\mathrm{pH}, \mathrm{Ca}$ and $\mathrm{Mg}$ content and base saturation (Table 4). A high correlation between the
$\mathrm{MBC}$ and organic $\mathrm{C}$ had been reported by Anderson \& Domsch (1989) and Balota et al. (1998). The significant relationship between the microbial biomass with organic $\mathrm{C}$ is likely due to higher organic matter levels that support greater microbial biomass with more activity. These findings suggest that microbial biomass compartments are inter-connected with soil C cycling.

There was a strong correlation between the microbial biomass $\mathrm{P}$ and available $\mathrm{P}\left(\mathrm{r}=0.79^{*}\right)$. The MBP was also increased due to soil $\mathrm{P}$ content, as similarly observed by Guerra et al. (1995) and Conte et al. (2002). However, it is not always the case that the MBP fraction is determined by the size of the microbial P pool (Brookes et al., 1982). The MBP may be increased due to the combination of the recent addition of phosphate fertilizer with a high $\mathrm{C}$ addition from the previous groundcover residues (Conte et al., 2002).

\section{Nutrient stock and flux through microbial biomass}

The estimates of the pool sizes of the microbial N and $\mathrm{P}$ stocks suggest that these pools were large enough to significantly affect plant nutrient availability. The average $\mathrm{N}$ contents of the microbial biomass pool were $45-85 \mathrm{~kg} \mathrm{ha}^{-1}$ under the tree canopy and 44-73 $\mathrm{kg} \mathrm{ha}^{-1}$ in the inter-row, while the $\mathrm{P}$ stock in the microbial biomass were $27-48 \mathrm{~kg} \mathrm{ha}^{-1}$ under the tree canopy and $11-27 \mathrm{~kg} \mathrm{ha}^{-1}$ in the interrow (Table 5), considering the top $15 \mathrm{~cm}$.

Calculating the average $\mathrm{N}$ and $\mathrm{P}$ required for the production of 21 - $30 \mathrm{t} \mathrm{ha}^{-1}$ of orange fruit, the required amounts would be around $140 \mathrm{~kg} \mathrm{~N}$ and $90 \mathrm{~kg}$ P. Assuming a turnover time of 1.25 year for the microbial nutrients (Jenkinson \& Ladd, 1981), the annual nutrient flux through the soil microbial biomass under the tree canopy was about $100 \mathrm{~kg} \mathrm{ha}^{-1}$ $\mathrm{N}$ for CT-Calopogonium and CT-brachiaria and $57 \mathrm{~kg} \mathrm{ha}^{-1} \mathrm{P}$ for CT-bahiagrass. These values mean that about $71 \%$ of the annual $\mathrm{N}$ and $63 \%$ of the annual $\mathrm{P}$ orange requirements are being met. A value

Table 4. Simple correlations (r) between microbial and chemical properties across all treatments and sampling positions

\begin{tabular}{|c|c|c|c|c|c|}
\hline Variable & Orga nic C & MBC & MBN & MBP & $\mathrm{C}_{\text {mic }}: \mathrm{C}_{\text {org }}$ \\
\hline MBC & $0.90^{*}$ & - & - & - & - \\
\hline MBN & 0.30 & 0.29 & - & - & - \\
\hline MBP & -0.07 & -0.30 & 0.32 & - & - \\
\hline $\mathrm{C}_{\text {mic }}$ :Corg & $0.77^{*}$ & $0.97^{*}$ & 0.29 & -0.38 & - \\
\hline $\mathrm{pH}$ & $0.68^{*}$ & $0.83^{*}$ & -0.21 & -0.69 & $0.82^{*}$ \\
\hline $\mathrm{Al}^{3+}$ & -0.59 & -0.77 & 0.28 & 0.68 & -0.80 \\
\hline $\mathrm{Ca}^{2+}$ & 0.61 & $0.78^{*}$ & 0.14 & -0.45 & $0.82^{*}$ \\
\hline $\mathrm{Mg}^{2+}$ & $0.71^{*}$ & $0.85^{*}$ & -0.16 & -0.66 & 0.83 \\
\hline CEC & -0.35 & -0.48 & 0.49 & 0.62 & -0.50 \\
\hline Base saturation & $0.68^{*}$ & $0.85^{*}$ & -0.20 & -0.62 & $0.86^{*}$ \\
\hline $\mathrm{P}$ & -0.48 & -0.61 & 0.31 & $0.79 *$ & -0.62 \\
\hline
\end{tabular}

pH: $\mathrm{CaCl}_{2}$ 0.01mol L-1; P: Extractable (Mehlich-1). *: significant at $(\mathrm{p} \leq 0.05)$. 
Table 5. Stocks of organic $\mathrm{C}, \mathrm{N}$ and $\mathrm{P}$ of microbial biomass and annual flux of $\mathrm{C}, \mathrm{N}$ and $\mathrm{P}$ through the microbial biomass (0-15 cm depth) under the tree canopy and in the inter-row as affected by different permanent groundcover species between the orange trees

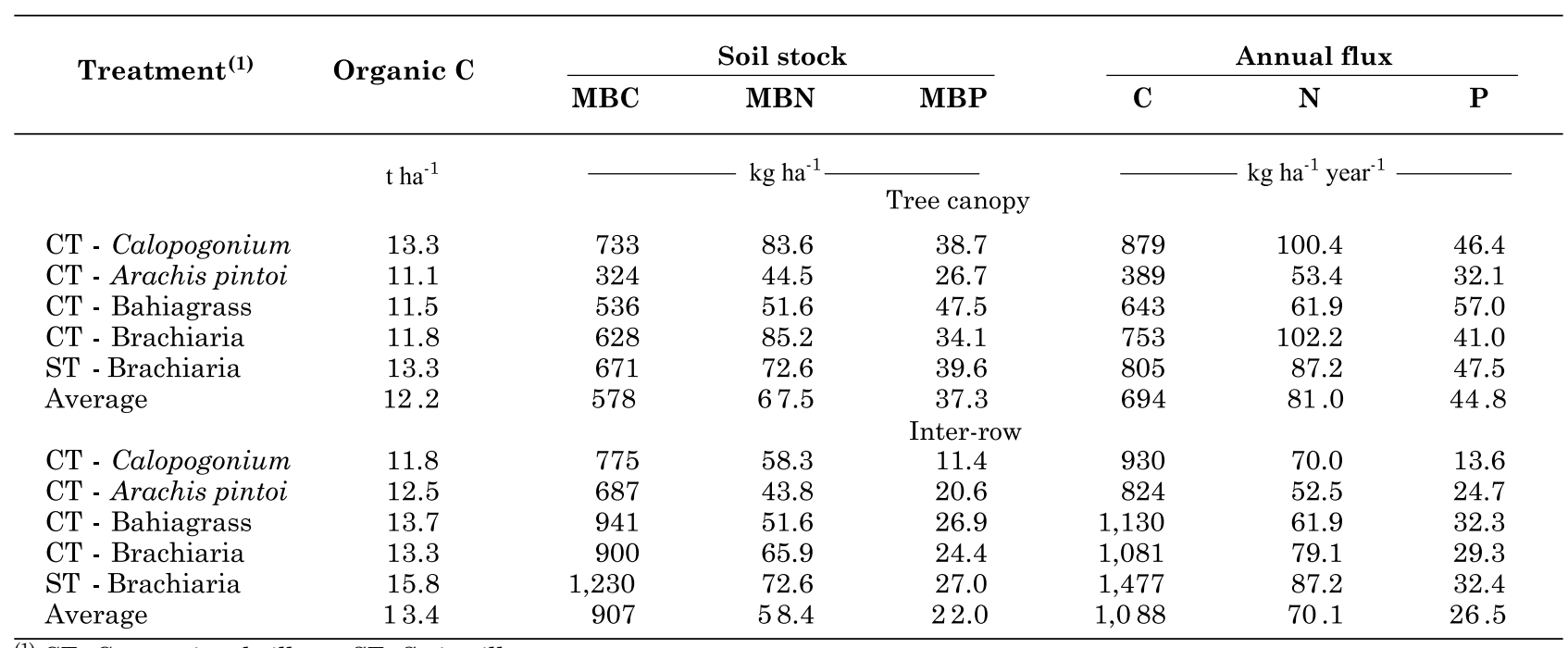

(1) CT: Conventional tillage; ST: Strip tillage.

of 1.25 years for the microbial biomass turnover time is a good estimate for tropical and subtropical conditions (Rheinheimer et al., 2000). Although the microbial biomass turnover time varies widely (from 0.10 to 4.76 year) under different conditions in the world, Gijsman et al. (1997) considered a value of around 1.0 year as a reasonable estimate for the tropics.

This observation confirmed that a significant part of the $\mathrm{N}$ and $\mathrm{P}$ requirement for plant growth may be mineralized from soil organic matter through microbial processes (Smith \& Paul, 1990). The soil microbial biota is important, not only because it plays an important role in the plant nutrient supply, but also because the organisms release nutrients little by little, synchronized with the plant nutrient demand. The microbial biomass immobilizes significant amounts of nutrients, decreasing the pools of free nutrients with consequential reductions in the nutrient losses by leaching or denitrification. These results are evidence that the microbial biomass represents a substantial nutrient reserve for orange trees. However, not all of the nutrients mineralized from the microbial biomass are available exclusively for crop growth each year; part of these available nutrients may be used by a subsequent generation of microorganisms, or adsorbed onto the soil colloids. Nevertheless, there is no doubt that the soil microbial biomass is an important source of plant nutrients.

\section{CONCLUSIONS}

1. The different groundcover species intercropped with the orange trees improved microbial biomass properties, under the tree canopy as well as in the inter-rows.
2. The cultivation of cover species enriched the soil microbial biomass in $\mathrm{N}$ and $\mathrm{P}$.

3. The decrease of soil disturbance increased the microbial biomass in the inter-row.

4. In the inter-row, $\mathrm{C}, \mathrm{N}$ and $\mathrm{P}$ in the microbial biomass of grass were higher than of legume.

\section{LITERATURE CITED}

ANDERSON, T.-H. \& DOMSCH, K.H. Quantities of plant nutrients in the microbial biomass of selected soils. Soil Sci., 130:211-216, 1980.

ANDERSON, T.-H. \& DOMSCH, K.H. Ratios of microbial biomass carbon to total organic carbon in arable soils. Soil Biol. Biochem., 21:471-479, 1989.

AULER, P.A.M.; FIDALSKI, J.; PAVAN, M.A. \& NEVES, C.S.V.J. Produção de laranja "Pêra" em sistemas de preparo de solo e manejo nas entrelinhas. R. Bras. Ci. Solo, 32:363-374, 2008.

BALOTA, E.L. \& CHAVES, J.C.D. Atividade microbiana em solos cultivados com leguminosas de verão intercalar no cafeeiro. In: SIMPÓSIO DE PESQUISA DOS CAFÉS DO BRASIL, 6., Vitória, 2009. Anais... Vitória, Embrapa/ Incaper, 2009. CD-ROM.

BALOTA, E.L.; COLOZZI-FILHO, A.; ANDRADE, D.S. \& DICK, R.P. Microbial biomass in soils under different tillage and crop rotation systems. Biol. Fert. Soils, 38:15-20, 2003.

BALOTA, E.L.; COLOZZI-FILHO, A.; ANDRADE, D.S. \& DICK, R.P. Long-term tillage and crop rotation effects on microbial biomass and $\mathrm{C}$ and $\mathrm{N}$ mineralization in a Brazilian Oxisol. Soil Tillage Res., 77:137-145, 2004. 
BALOTA, E.L.; COLOZZI-FILHO, A.; ANDRADE, D.S. \& HUNGRIA, M. Biomassa microbiana e sua atividade em solos sob diferentes sistemas de preparo e sucessão de Culturas. R. Bras. Ci. Solo, 22:641-649, 1998.

BEARE, M.H.; CABRERA, M.L.; HENDRIX, P.F. \& COLEMAN, D.C. Aggregate-protected and unprotected organic matter pools in conventional and no-tillage soils. Soil Sci. Soc. Am. J., 58:787-795,1994.

BHERING, S.B. \& SANTOS, H.G. Mapa de solos do estado do Paraná: Legenda atualizada. Rio de Janeiro, Embrapa Florestas/Embrapa Solos/Instituto Agronômico do Paraná, 2008. 74 p.

BERALDO, J.M.G.; AULER, P.A.M.; PAVAN, M.A. \& FIDALSKI, J. Reciclagem de nutrientes num pomar de laranjeira "Pera" com diferentes sistemas de preparo do solo e Cobertura vegetal. In: CONGRESSO BRASILEIRO DE CIÊNCIA DO SOLO, 31, Gramado, 2007. Anais... Gramado, 2007. CD ROM.

BROOKES, P.C.; LANDMAN, A.; PRUDEN, G. \& JENKINSON, D.S. Chloroform fumigation and the release of soil nitrogen: A rapid direct extraction method to measure microbial biomass nitrogen in soil. Soil Biol. Biochem., 17:837-842, 1985.

BROOKES, P.C.; POWLSON, D.S. \& JENKINSON, D.S Measurement of microbial biomass phosphorus in the soil. Soil Biol. Biochem., 14:319-329, 1982.

CHAVES, J.C.D.; PAVAN, M.A. \& CALEGARI, A. Adição de matéria seca e nutrientes através da utilização de plantas para cobertura em culturas perenes e seus efeitos sobre a reação do solo. Braz. Arch. Biol. Technol., 40:47-44, 1997.

CONTE, E.; ANGHINONI, I. \& RHEINHEIMER, D.S. Fósforo da biomassa microbiana e atividade de fosfatase ácida após aplicação de fosfato em solo no sistema plantio direto. R. Bras. Ci. Solo, 26:925-930, 2002.

D’ANDRÉA, A.F.; SILVA, M.L.N.; CURI, N.; SIQUEIRA, J.O. \& CARNEIRO, M.A.C . Atributos biológicos indicadores da qualidade do solo em sistemas de manejo na região do cerrado no sul do Estado de Goiás. R. Bras. Ci. Solo, 26:913923, 2002 .

DICK, R.P. A review: Long-term effects of agricultural systems on soil biochemical and microbial parameters. Agric. Ecosyst. Environ., 40:25-36,1992.

DUDA, G.P.; GUERRA, J.MG.; MONTEIRO, M.T.; DE-POLLI, H. \& TEIXEIRA, M.G. Perennial herbaceous legumes as live soil mulches and their effects on $\mathrm{C}, \mathrm{N}$ and $\mathrm{P}$ of the microbial biomass. Sci. Agric., 60:139-147, 2003.

FIDALSKI, J. \& TORMENA, C.A. Dinâmica da calagem superficial em um Latossolo Vermelho distrófico. R. Bras.Ci. Solo, 29:235-247, 2005.

FIDALSKI, J.; MARUR, C.J. \& TORMENA, C.A. Respostas fisiológicas da laranjeira "Pêra" aos sistemas de manejo de Cobertura permanente do solo nas entrelinhas. R. Bras. Ci. Solo, 32:1307-1317, 2008.
FIDALSKI, J.; TORMENA, C.A. \& SILVA, A.P. Qualidade física do solo em pomar de laranjeira no noroeste do Paraná com manejo da cobertura permanente na entrelinha. R. Bras. Ci. Solo, 31:423-433, 2007.

FRANCHINI, J.C.; PAVAN, M.A. \& MIYAZAWA, M. Redistribution of phosphorus in soil through cover crop roots. Braz. Arch. Biol. Technol., 47:381-386, 2004.

GIJSMAN, A.J.; OBERSON, A.; FRIESEN, D.K.; SANZ, J.I. \& THOMAS, R.J. Nutrient cycling through microbial biomass under rice-pasture rotations replacing native savanna. Soil Biol. Biochem., 29:1433-1414, 1997.

GUERRA, J.G.M.; FONSECA, M.C.C.; ALMEIDA, D.L.; DEPOLLI, H. \& FERNANDES, M.S. Conteúdo de fósforo da biomassa microbiana de um solo cultivado com Brachiaria decumbens Stapf. Pesq. Agropec. Bras., 30:543-551, 1995.

HE, Z.L.; WU, J.; O’DONNEL, A.G. \& SYERS, J.K. Seasonal responses in microbial biomass carbon, phosphorus and sulphur in soils under pasture. Biol. Fert. Soils, 24:421428, 1997.

JENKINSON, D.S. \& LADD, J.N. Microbial biomass in soil: Measurement and turnover. In: PAUL, E.A. \& LADD, J.M., eds. Soil biochemistry. New York, Marcel Decker, 1981. p.415-471.

JOERGENSEN, R.G.; KÜBLER, H.; MEYER, B. \& WOLTERS, V. Microbial biomass phosphorus in soils of beech (Fagus sylvatica) forests. Biol. Fert. Soils, 19:215-219, 1995.

KASCHUK, G.; ALBERTON, O. \& HUNGRIA, M. Three decades of soil microbial biomass studies in Brazilian ecosystems: Lessons learned about soil quality and indications for improving sustainability. Soil Biol. Biochem., 42:1-13, 2010.

KUMAR, R.; PANDEY, S. \& PANDEY, A. Plant roots and carbon sequestration. Curr. Sci., 91:885-890, 2006.

MEDA, A.R.; CASSIOLATO, M.E.; PAVAN, M.A. \& MIYAZAWA, M. Alleviating soil acidity through plant organic compounds. Braz. Arch. Biol. Technol., 44:185189, 2001.

MIYAZAWA, M.; CHIERICE, G.O. \& PAVAN, M.A. Amenização da toxidade de alumínio às raízes do trigo pela complexação com ácidos orgânicos. R. Bras. Ci. Solo, 15: 209-215, 1992.

NEVES, C.S.V.J. \& DECHEN, A.R. Sistemas de manejo de solo em pomar de tangerina Ponkan sobre limão Cravo em Latossolo Roxo. Laranja, 22:167-184, 2001.

NORTON, J.M.; SMITH, J.L. \& FIRESTONE, M.K. Carbon flow in the rhizosphere of ponderosa pine seedlings. Soil Biol. Biochem., 22:449-455, 1990.

ORIOLI, F.P. Antecipação da adubação nitrogenada na cultura do milho sob pastagem de capim braquiária. Brasília, Universidade de Brasília, 2008. 72p. (Tese de Mestrado)

PAUL, E.A. \& CLARK, F.E. Soil microbiology and biochemistry. San Diego, Academic Press, 1996. p.340. 
PAVAN, M.A.; BLOCH, M.F.; ZEMPULSKI, H.C.; MIYAZAWA, M. \& ZOCOLER, D.C. Manual de análise química de solo e Controle de qualidade. Londrina, IAPAR, 1992. 40p. (Circular Técnica, 76)

POLITANO, W. \& PISSARRA, T.C.T. Avaliação por fotointerpretação das áreas de abrangência dos diferentes estados da erosão acelerada do solo em canaviais e pomares de Citros. Eng. Agríc., 25:242-252, 2005.

POWLSON, D.S.; BROOKES, P.C. \& CHRISTENSEN, B.T. Measurement of soil microbial biomass provides an early indication of changes in the total soil organic matter due to straw incorporation. Soil Biol. Biochem., 19, 159-164, 1987.

POWLSON, D.S. \& JENKINSON, D.S. A comparison of the organic matter, biomass, adenosine triphosphate and mineralizable nitrogen contents of ploughed and directdrilled soils. J. Agric. Sci., 97:713-721, 1981.

RHEINHEIMER, R.S.; ANGHINONI, I. \& CONTE, E. Fósforo da biomassa microbiana em solos sob diferentes sistemas de manejo. R. Bras. Ci. Solo, 24:589-597, 2000.

SANTOS, R.S.M.; OLIVEIRA, I.P.; MORAIS, R.F.; URQUIAGA, S.C.; BODDEY, R.M. \& ALVES, B.J.R. Componentes da parte aérea e raízes de pastagens de Brachiaria spp. em diferentes idades após a reforma, como indicadores de produtividade em ambiente de Cerrado. Pesq. Agropec. Trop., 37:19-124, 2007.

SAS. SAS Institute. SAS/STAT User's guide: Statistics. 9.ed. Cary, 2002.

SINGH, H, \& SINGH, K.P. Effect of residue placement and chemical fertilizer on soil microbial biomass under tropical dryland cultivation. Biol. Fert. Soils, 16:275-281, 1993.

SINGH, S.; GHOSHAL, N. \& SINGH, K.P. Variations in soil microbial biomass and crop roots due to differing resource quality in a tropical dryland agroecosystem. Soil Biol. Biochem., 39:76-86, 2007.
SMITH, J.L. \& PAUL, E.A. The significance of microbial biomass estimations. In: BOLLAG, J.M. \& STOZKY, G., eds. Soil biochemistry. New York, Marcel Decker, 1990. p.357-396

SOIL SURVEY STAFF. Soil taxonomy: A basic system of soil classification for making and interpreting soil surveys. 2.ed. Washington, US Department of Agriculture, 1999. 869p.

SPARLING, G.P. Ratio of microbial biomass carbon to soil organic carbon as a sensitive indicator of changes in soil organic matter. Austr. J. Soil Res., 30, 195-207, 1992.

SPARLING, G.P. Soil microbial biomass, activity and nutrient cycling as indicators of soil health. In: PANKHURST, C.; DOUBE, B.M. \& GUPTA, V.V.S.R., eds. Biological indicators of soil health. London, CAB International, 1997. p.97-119.

VALENTIN, J.F.; CARNEIRO, J.C. \& SALES, M.F.L. Amendoim forrageiro cv. leguminosa para a diversificação das pastagens e Conservação do solo no Acre. Belmonte, Embrapa, 2001. p.17. (Circular Técnica 43)

VANCE, E.D.; BROOKES, P.C. \& JENKINSON, D.S. An extraction method for measuring soil microbial biomass carbon. Soil Biol. Biochem., 19:703-707, 1987.

WENDLING, I.J.; CARNEIRO, J.C.; VALENTIM, J.F. \& FEITOSA, J.E. Efeito da frequência de Corte na produção de matéria seca de Arachis pintoi (BRA-031143) nas condições edafoclimáticas do Acre. In: REUNIÃO ANUAL DA SOCIEDADE BRASILEIRA DE ZOOTECNIA, 36., Porto Alegre, 1999. Anais...Porto Alegre, SBZ, 1999. CD ROM.

WHIPPS, J.M. Carbon economy. In: LYNCH, J.M., ed. The rhizosphere. New York, John Wiley \& Sons, 1990. p.5997. 
